\title{
CONFIDENTIALITY AND DISCLOSURE IN ACCREDITATION
}

\author{
TIMOTHY STOLTZFUS JOST
}

I

\section{INTRODUCTION}

Accrediting bodies possess a great deal of sensitive information: data harvested from accredited institutions through reports and inspection surveys; intelligence provided by persons with an interest in influencing accreditation decisions (including administrators, staff, employees, consumers, and complainants); decisions and reports generated by the accreditor in the accreditation process; and material regarding accreditation standards and procedures.

Indeed, accrediting bodies are in the information business. ${ }^{1}$ Their primary tasks include generating information in the form of accreditation standards that define acceptable performance within a field, assembling information about institutions that desire accreditation under those standards, processing that information through various decisionmaking algorithms, and ultimately producing information as to which institutions meet or fail to meet those standards. Issues of control of information are thus of prime importance to both accrediting bodies and those affected by their decisions. This article considers these issues.

\section{II}

\section{INFORMATION CONTROL AND THE ROLE OF ACCREDITATION}

Historically, accrediting bodies have maintained strict confidentiality of information provided to them and of information generated in the accreditation process. $^{2}$ This secrecy was grounded in the notion that accreditation was fundamentally a process of peer review for self-improvement. ${ }^{3}$ Information generated in that process was for the benefit of the reviewed institution and was nobody else's business. ${ }^{4}$ Information was also kept confidential because of a

Copyright (C) 1995 by Law and Contemporary Problems

* Newton D. Baker, Baker and Hostetler Chair in Law and Professor of Hospital and Health Services Administration, The Ohio State University.

1. See Clark C. Havighurst \& Nancy M. P. King, Private Credentialing of Health Care Personnel: An Antitrust Perspective (pt. 1), 9 AM. J.L. \& MED. 131, 134-38 (1983) (discussing the informational nature of accreditation).

2. PERSPECTIVES ON ACCREDITATION (Joint Commission on Accreditation of Health Care Organizations), Jan. 1972, at 3; Courtney Leatherman, Disclosure Policies Make it Tough to Get Details of Colleges' Accreditation Status, CHRON. HIGHER EdUC., Jan. 6, 1993, at A16.

3. Louis H. HEILBRON, CONFIDENTIALITY AND ACCREDITATION 10 (1976); Carl P. Schlicke, Does the Joint Commission have a Future?, AM. SURGEONS BULL., Apr. 1978, at 7, 9.

4. HEILBRON, supra note 3; Schlicke, supra note 3. 
belief that openness and full disclosure to the accreditor by the entity seeking accreditation was fundamental to the peer review process, and that this disclosure would be significantly chilled if the information disclosed could be made public. ${ }^{5}$ Under this peer review vision of accreditation, confidentiality of information makes considerable sense.

There are, however, two alternative visions of the role of accreditation. First, an accreditor could act as a private (or quasi-private) agent of public regulation. ${ }^{6}$ Regulation of the quality of goods and services in particular markets is arguably necessary because of market failures, which are normally attributable to the lack of information. ${ }^{7}$ In the institutional health care sector, for example, it is difficult for consumers to make informed purchasing decisions, both because of the complexity of the product to be purchased and because of the general inability of any one consumer to gain sufficient experience to be able to evaluate the product. ${ }^{8}$ Either because the government wishes to avoid the cost of policing the market itself, or because a private accreditor possesses advantages that make it a superior regulator, the government may choose to rely on industry self-regulation through industry standard-setting or accreditation. ${ }^{9}$ Once the accreditor becomes a regulator, however, the government may insist on access to information in the hands of the accreditor to assure its accountability. ${ }^{10}$ To further assure accountability of the regulatory program to the public, the public itself may need access to accreditation information under some circumstances. ${ }^{11}$ Under this model, disclosure to the government is necessary, and absolute confidentiality is not possible.

The second alternative model views accreditation as a means of assisting consumers in comparing the quality of competing suppliers of goods and services. If markets fail to operate efficiently because of the absence of useful information about goods and services, a clear solution is to produce more or

5. This argument parallels closely the argument traditionally made for protecting confidentiality in medical peer review proceedings within institutions. See Bredice v. Doctors Hosp. Inc., 50 F.R.D. 249, 250 (D.D.C. 1970), aff'd, 479 F.2d 920 (D.C. Cir. 1973); Coburn v. Seda, 677 P.2d 173, 176-77 (Wash. 1984).

6. Kenneth J. Meier, Regulation: Politics, BureauCraCy, AND Economics 77-78, 176-77 (1985); Timothy Stoltzfus Jost, The Necessary and Proper Role of Regulation to Assure the Quality of Health Care, 25 Hous. L: REV. 525, 571-72 (1988).

7. MEIER, supra note 6, at 77-78, 176-77; Jost, supra note 6, at 571-72.

8. Jost, supra note 6 , at 560-64.

9. See Ross E. Cheit, Setting Safety Standards: Regulation in the Public and Private Sectors 19, 202-05 (1990); Douglas C. MiChaEl; Federal AgENCY Use Of Audited SElFRegulation As A Regulatory TeChNiQue 11-20 (1993) (Preliminary Draft for the Administrative Conference of the United States) (to be published in 47 ADMIN. L. REV., No. 2 (1995)); Timothy Stoltzfus Jost, Medicare and the Joint Commission on Accreditation of Healthcare Organizations: A Healthy Relationship?, 57 LAw \& CONTEMP. PROBS. 15 (Autumn 1994).

10. See 42 U.S.C. $\$ 1395$ bb (Supp. III 1991) (requiring hospitals certified for Medicare on the basis of Joint Commission accreditation to release their accreditation reports to the Department of Health and Human Services on request); Jost, supra note 9 (discussing these provisions).

11. Joint Commission reports may be disclosed to the public in the context of enforcement proceedings, for example. See infra text accompanying note 44 . 
better information. ${ }^{12}$ Accreditation could, in theory, inform consumers that the care provided by a particular accredited institution was of acceptable quality, or, even better, provide consumers with a quality scorecard allowing them to "comparison shop" among institutions. ${ }^{13}$ With quality information in hand, consumers would be able to focus on price, making the market more competitive. Under this vision of accreditation, disclosure of at least some information becomes essential. Confidentiality must, in turn, be circumscribed.

In fact, all three of these visions of accreditation to some extent describe the roles of health care and educational accreditation bodies in the United States. Institutions rely on accreditation for peer review and self-improvement. The government relies on accreditation for various regulatory purposes. Finally, the public relies on accreditation to identify entities providing services of acceptable quality and may increasingly demand comparative information from accreditors as well. Accreditation disclosure and confidentiality policy must, therefore, accommodate all three of these interests.

It must, however, accommodate other interests as well. ${ }^{14}$ First, accredited institutions may have legitimate interests in some level of confidentiality. Institutions seeking accreditation may disclose sensitive information, such as financial data, to the accrediting bodies; public disclosure of such information could give competitors an unfair advantage or otherwise harm the institution. ${ }^{15}$ For example, proposals to purchase real estate could, if revealed, affect the price of the property. Likewise, information regarding adverse treatment results or suspected negligence could be relevant in litigation against the institution or its staff. Similarly, professionals who have provided information to the accrediting body in confidence (including administrators, employees, faculty, and medical staff), along with consumers who have made statements critical of the institution or of its administrators or employees, may want this information (or at least their identities) kept confidential. ${ }^{16}$ There is also a significant risk of liability on the part of accrediting agency if derogatory accreditation information is

12. See U.S. Office of Technology Assessment, The Quality of Medical Care: INFORMATION FOR CONSUMERS 187-205 (1988) (discussing generally the value of information for consumers of medical care, and specifically the value of accreditation information); Havighust \& King, supra note 1, at 134-38 (discussing the use of certification for facilitating consumer choice).

13. See U.S. OFFICE OF TECHNOLOGY ASSESSMENT, supra note 12; Havighust \& King, supra note 1 , at $134-38$.

14. Perhaps the best consideration of the various interests at stake in control of health care information is still the Institute of Medicine Study on Professional Standards Review Organization disclosure policy, summarized in Searching for a Balance in Medical Data Disclosure, HEALTH AFFAIRS, Winter 1981, at 62 .

15. HEILBRON, supra note 3, at 10,11; see also cases cited infra note 55 (involving attempts by medical negligence plaintiffs to discover accreditation information).

16. HEILBRON, supra note 3, at 10,11. Employee fear of reprisals for giving accreditors information critical of employing institutions may be well grounded. See, e.g., Misericordia Hosp. Medical Ctr. v. NLRB, 623 F.2d 808 (2d Cir. 1980) (nurse fired for providing adverse information on hospital to JCAHO). The Joint Commission will on request protect the anonymity of persons who complain about accredited institutions. Telephone interview with Eleanor Wagner and Harold Bressler, General Counsel's Office, JCAHO (July 22, 1993). 
widely disclosed. ${ }^{17}$ The accomodation of these interests is the subject of the remainder of this article.

\section{III}

\section{DisClOSURE TO GOVERNMENT AGENCIES}

Historically, .the confidentiality of accreditation information has been protected by the internal policies of accrediting entities and by law. ${ }^{18}$ Increasingly, however, as regulators have come to rely on accreditation decisions for public purposes, the trend has been for government to demand greater access to accreditation information. ${ }^{19}$

In the health care area, this movement has been clear. The original 1965 Medicare statute permitting deemed status for hospitals accredited by the Joint Commission on Accreditation of Hospitals (the "JCAH"), now the Joint Commission on Accreditation of Healthcare Organizations (the "JCAHO" or the "Joint Commission"), did not authorize the then Department of Health, Education, and Welfare ("HEW") to seek disclosure of accreditation information. ${ }^{20}$ HEW would only be informed of the accreditation status of hospitals and of the withdrawal of accreditation status, not of the analysis supporting particular accreditation decisions. ${ }^{21}$ This position was undoubtedly based on the traditional view that accreditation information was confidential peer review information.

Within five years, however, a controversy arose, first as to whether it was appropriate, or indeed constitutional, for Congress to delegate to accrediting agencies nonreviewable discretion to determine Medicare certification status, and second, assuming that it was not, as to whether HEW needed access to accreditation reports to hold the Joint Commission accountable for its accreditation decisions. ${ }^{22}$ In response to these concerns, the Social Security Act was amended in 1972 to permit both random and complaint-based validation

17. See Avins v. White, 627 F.2d 637 (3d Cir.), cert. denied, 449 U.S. 982 (1980) (permitting lawsuit against ABA accreditation consultant to proceed for allegedly defamatory remarks made during the accreditation process); American Int'l Hosp. v. Chicago Tribune Co., 483 N.E.2d 965 (Ill. App. 1985) (affirming dismissal of defamation suit brought by hospital denied accreditation against Joint Commission and newspaper); see also Peter H. Schuck, Tort Liability to Those Injured by Negligent Accreditation Decisions, 57 LAW \& CONTEMP. Probs. 185 (Autumn 1994).

18. The Wall of Confidentiality Around Joint Commission Survey Reports Continues to Crumble, 8 HOSP. L. NEWSLETTER, Feb. 1991, at 1 [hereinafter The Wall of Confidentiality].

19. Joint Commission to Share Information with State and District Licensure Agencies, JoINT COMM'N PERSPECTIVES (Joint Comm'n on Accreditation of Healthcare Orgs.), Nov./Dec. 1989, at 8; General Counsel's Office, Joint Comm'n on Accreditation of Healthcare Orgs., Development of JCAHO Confidentiality Guidelines, 24 J. HEALTH \& HosP. L. 134 (1991); The Wall of Confidentiality, supra note 18 , at 1 .

20. Social Security Amendments of 1965, Pub. L. No. 89-97, $\$ \$ 1861(\mathrm{e})(8), 1865,79$ Stat. 286, 315, 326-27 (codified as amended at 42 U.S.C. $\$ \S 1395 \times(e)(9), 1395 b b(1988)$ ).

21. Id.

22. See William Worthington \& Laurens H. Silver, Regulation of Quality of Care in Hospitals: The Need for Change, 35 LAW \& CONTEMP. PROBS. 305 (Spring 1970). 
inspections and to require disclosure of accreditation decisions by hospitals to HEW for validation purposes. ${ }^{23}$

The 1972 amendments permitted disclosure only to the degree necessary to permit agency monitoring of private accreditation efforts. The 1989 amendments to the Medicare statute went further, permitting the Department of Health and Human Services ("HHS") to require disclosure of reports from all accredited hospitals, not just from those subject to validation. ${ }^{24}$ The current federal statute requires institutions seeking deemed status to authorize the JCAHO

to release to the Secretary upon his request (or such State agency as the Secretary may designate) a copy of the most current accreditation survey of such institution made by such Commission, together with any other information directly related to the survey as the Secretary may require (including corrective action plans). ${ }^{25}$

It also requires the Joint Commission to release this information. ${ }^{26}$ Recently adopted regulations include these statutory requirements. ${ }^{27}$

23. Social Security Amendments of 1972, Pub. L. No. 92-603, \& 244, 86 Stat. 1329, 1422-23 (codified as amended at 42 U.S.C. $\$ \S 1395 x, 1395 z, 1395 a a, 1395 \mathrm{cc}(1988)$ ).

24. The amendments also authorized the Secretary to make public such information to the extent it related to an enforcement action taken by the Secretary. Omnibus Budget Reconciliation Act of 1989, Pub. L. No. 101-239, \& 6019(a), 103 Stat. 2106, 2165-66 (codified as amended at 42 U.S.C. § 1395bb (Supp. III 1991)).

25. 42 U.S.C. $\S 1395 b b(a)(2)$ (Supp. III 1991).

26. Id.

27. 58 Fed. Reg. $61,816,61,837-38,61,840$ (1993). Under these rules, 42 C.F.R. $\$ 401.126(b)(2)$ reads as follows:

(2)(i) Except as specified in paragraph (b)(2)(ii) of this section, HCFA may not disclose any accreditation survey or any information directly related to the survey (including corrective action plans) made by and released to it by the Joint Commission on Accreditation of Healthcare Organizations, the American Osteopathic Association or any other national accreditation organization that meets the requirements of $\S 488.6$ or $\$ 493.506$ of this chapter. Materials that are confidential include accreditation letters and accompanying recommendations and comments prepared by an accreditation organization concerning the entities it surveys.

(ii) Exceptions. (A) The Secretary may release the accreditation survey of any home health agency; and

(B) The Secretary may release the accreditation survey and other information directly related to the survey (including corrective action plans) to the extent the survey and information relate to an enforcement action taken by HCFA ... .

Section 401.133 is amended by adding new paragraphs (d) and (e) to read as follows:

The following shall be made available to the public under the conditions specified: . .

(d) Accreditation surveys. Upon written request, HCFA may release the accreditation survey and related information from an accreditation organization meeting the requirements of $\S 488.5$ or $\S 488.6$ or $\S 493.506$ of this chapter to the extent the survey and information relate to an enforcement action taken . .. by HCFA ....

(e) Upon written request, HCFA will release the accreditation survey of any home health agency.

Section $\mathbf{4 8 8 . 5}$ is revised to read as follows:

(c)(1) A provider or supplier deemed to meet program requirements under paragraph (a) of this section must authorize its accreditation organization to release to HCFA and the State survey agency a copy of its most current accreditation survey, together with any information related to the survey that 
The requirements of the Clinical Laboratories Improvement Amendments of 1988 ("CLIA") $)^{28}$ are similar but somewhat more sophisticated. CLIA permits HHS to certify accredited laboratories if the accreditation program meets certain requirements. It further requires HHS to make available annually to physicians and to the general public, inter alia, "a list of laboratories whose accreditation has been withdrawn or revoked together with a statement of the reasons for withdrawal or revocation."29 Regulations implementing the Act require that accreditation agencies supply the Health Care Financing Agency ("HCFA") with electronic data related to adverse actions stemming from proficiency testing results as well as data on proficiency testing failures. ${ }^{30}$ The accreditation agencies must also notify HCFA within ten days of deficiencies they identify in accredited laboratories when such deficiencies pose an immediate threat to the laboratory's patients or a hazard to the general public. $^{31}$

The federal government also relies on educational accreditation for certain purposes, primarily for awarding student aid. ${ }^{32}$ The Higher Education Act $^{33}$ (the "HEA") requires disclosure to the Secretary of Education within thirty days of adverse actions (including probations) imposed by accreditation bodies. $^{34}$ It further requires disclosure to both the Secretary of Education and to the public of a summary of reviews resulting in termination, suspension, or denial of accreditation, together with the comments of affected institutions. ${ }^{35}$

In order for an accrediting agency to earn approval from the Secretary, it must maintain and make available to the public written materials describing its own standards and procedures for accreditation and appeals, as well as information regarding the accreditation status of each institution under its jurisdiction. ${ }^{36}$ The Department of Education must also disclose to the public

HCFA may require (including corrective action plans).

(2) HCFA may determine that a provider or supplier does not meet the Medicare conditions on the basis of its own investigation of the accreditation survey or any other information related to the survey.

(3) Upon written request, HCFA may disclose the survey and information related to the survey-

(i) Of any HHA; or

(ii) Of any other provider or supplier specified at paragraph (a) of this section if the accreditation survey and related survey information relate to an enforcement action taken by HCFA.

28. 42 U.S.C. $\S 263(\mathrm{a})$.

29. Id. \& $263 \mathrm{a}(\mathrm{n})(4)$.

30. 42 C.F.R. \& 493.506(b)(2)(v) (1992).

31. Id. $\$ 493.506(\mathrm{~b})(3)(\mathrm{ii})$.

32. 20 U.S.C. $\$ 1099 \mathrm{~b}$ (Supp. IV 1992); see also Matthew W. Finkin, The Unfolding Tendency in the Federal Relationship to Private Accreditation in Higher Education, 57 LAW \& CONTEMP. PROBS. 89 (Autumn 1994); Jeffrey C. Martin, Recent Developments Concerning Accrediting Agencies in Postsecondary Education, 57 LAW \& CONTEMP. PROBS. 121 (Autumn 1994).

33. 20 U.S.C. $\$ \S 1001-1145(1988)$.

34. Id. \& 1099b(a)(7) (Supp. IV 1992).

35. Id. \& $1099 \mathrm{~b}(\mathrm{a})(8)$.

36. Id. § $1099 \mathrm{~b}(\mathrm{c})(5)$. 
the fact that it is considering an institution of higher education under its jurisdiction for accreditation or reaccreditation. ${ }^{37}$ Regulations implementing the 1992 amendments require educational accrediting agencies to submit "[u]pon request of the Secretary information regarding an accredited or preaccredited institution's compliance with its Title IV, HEA program responsibilities, including its eligibility to participate in Title IV, HEA programs, for the purpose of assisting the Secretary in resolving problems with the institution's participation in these programs." 38 Higher education regulations previously in place had merely required accreditation agencies to notify HHS within thirty days of decisions to withdraw accreditation or to place institutions on publicly announced probation. ${ }^{39}$

In addition to the federal government, states rely on accreditation information for making licensure or other decisions. Pursuant to this reliance, state governments also often require information from the accrediting bodies as to the basis of their decisions. Approximately forty-two states and the District of Columbia rely on JCAHO accreditation in whole or in part for licensing health care institutions. ${ }^{40}$ Several of these state statutes (thirty-two by the JCAHO's count) require institutions seeking licensure to disclose survey reports to the state agency. ${ }^{41}$

37. Id. § $1099 \mathrm{~b}(\mathrm{c})(6)$.

38. 59 Fed. Reg. $22,250,22,255$ (1994). The proposed rule had required accrediting agencies to submit "[u]pon request, information to assist the Secretary in resolving problems with any institution or program accredited by the agency, provided that the request does not conflict with the agency's policies on confidentiality with respect to its records on those institutions or programs." Id. at 3578, 3592. This rule was limited in its scope because of many comments received by the department claiming that the requirement would compromise the confidentiality necessary for peer review. See id. at 22,266 . The department's response to these comments notes that under its final rule,

... an agency does not have to provide the Secretary with copies of an institution's self-study report, reports of on-site evalutations of the institution by the accrediting agency, or other documents maintained by the agency about the institution for the purpose of determining the institution's compliance with the agency's standards. However, the agency must provide any information contained in those documents that is relevant to the institution's compliance with its Title IV, HEA program responsibilities.

Id. at 22,267 .

39. 34 C.F.R. $\S 602.16(f)(1993)$.

40. Joint Comm'n on Accreditation of Healthcare Orgs., State Project Status Report (July 15, 1992) (unpublished memorandum, on file with the author) [hereinafter JCAHO State Status Report]; see, e.g., ALASKA STAT. \& 18.20.080(a) (1993) (hospitals); GA. CODE ANN. \& 31-7-3(b) (1991) (health facilities); IOWA CODE ANN. § 135J.2 (West Supp. 1993) (hospices); MD. CODE ANN., HeAlTH-GEN. \$ 8-403(d) (alcohol and drug abuse treatment programs), $\$ 10-504$ (1994) (mental health facilities); Mo. REV. STAT. § 630.705(3), (6) (Supp. 1993) (mental hospitals); N.C. GEN. STAT. § 131E-138(g) (1993) (home health agencies); OHIO REV. CODE ANN. \& 3727.02(a) (Baldwin 1993) (hospitals).

41. JCAHO State Status Report, supra note 40; see, e.g., FLA. STAT. ANN. \&395.0161 (West 1993); MD. CODE ANN., HEALTH-GeN. \& 19-308(c) (Supp. 1993); MINN. STAT. \& 144.55, subd. 4 (Supp. 1993); TEnN. CODE ANN. § 68-11-210(b)(5)(B) (Supp. 1993). 


\section{Public Disclosure of ACCREDITATION INFORMATION by GOVERNMENT AGENCIES}

Statutes that permit disclosure of accreditation documents to the government obviously raise the possibility that the government might make that information public. In 1975, HEW released to consumer organizations (who had filed a Freedom of Information Act request) deficiency letters that it had obtained from the Joint Commission under the 1972 statute. ${ }^{42}$ When the Joint Commission sued to maintain confidentiality of this information, the suit was settled with HEW agreeing not to release Joint Commission accreditation letters or accompanying recommendations or comments. ${ }^{43}$ The federal statute, regulations, and proposed regulations on health care accreditation now specifically prohibit public disclosure except "to the extent that information is related to an enforcement action." ${ }^{44}$ This exception is based on the obvious fact that the government cannot take enforcement action based on adverse accreditation information unless it is able to introduce in subsequent proceedings evidence gained from accreditation agencies. Beyond this narrow exception, public disclosure of information gained by the government with respect to most accredited health care institutions is prohibited.

There is, however, one category exempted from the general policy of nondisclosure of health care information: accreditation reports regarding home health agencies are fully subject to public disclosure. ${ }^{45}$ Deemed Medicare certification status for accredited home health agencies was adopted in the face of serious concerns raised by consumer groups. ${ }^{46}$ This opposition was related to even more widespread opposition to deemed status for nursing homes, which surfaced in response to Reagan Administration proposals to rely on nursing home accreditation for determining federal participation status. ${ }^{47}$ Requiring full disclosure of home health accreditation reports-permitting greater public

42. Timothy Stoltzfus Jost, The Joint Commission on Accreditation of Hospitals: Private Regulation of Health Care and the Public Interest, 24 B.C. L. REv. 835, 856-57 (1983).

43. Joint Comm'n on Accreditation of Hosps. v. Weinberger, No. 75 C 175 (N.D. Ill. Oct. 8, 1975) (dismissed by stipulation).

44. 42 U.S.C. $\$ 1395$ bb (Supp. III 1991); 42 C.F.R. $\$ 401.126(b)(2)$ (quoted supra note 27).

45. 42 U.S.C. \& 1395 bb.

46. The American Bar Association's Commission on Legal Problems of the Elderly played a leading role in this debate. In August 1986, the Commission released a report entitled THE BLACK BOX OF HOME CARE QUALITY through the House Select Committee on Aging, reviewing regulation of the quality of home care. In August 1987, the ABA House of Delegates adopted a policy recommendation based on this report, which, inter alia, resolved that "deemed status" be extended to accredited home health agencies only if certain conditions were met, including the full accessibility of survey results to the public.

47. See Institute of Medicine, ImPRoving the Quality of CARE IN NURsing Homes 1-2 (1986); Jost, supra note 42, at 844; see also Iris C. Freeman, Blast or Boost? How the Joint Commission Fared in the Institute of Medicine's Nursing Home Study, QRB, Dec. 1986, at 415. 
oversight of the home health accreditation process-made deemed status somewhat more palatable to these groups.

Public disclosure has been less of an issue in the education area. Such information, when disclosed to the Department of Education, may be made public under the Freedom of Information Act, but it would be subject to the act's exceptions, such as the exception for confidential commercial or financial information. ${ }^{48}$ Under rules implementing the Higher Education Act amendments, confidential agency materials examined by the Department would not become part of the Department's permanent files on the agency, presumably to assure that they not become public under the Freedom of Information Act. ${ }^{49}$

At the state level, seventeen of the states that rely on Joint Commission accreditation for licensure prohibit redisclosure of Joint Commission accreditation information to the public (subject to some exceptions, such as the Rhode Island exception for imminent dangers to public health). ${ }^{50}$ Fourteen of the states that rely on accreditation for licensure make accreditation reports available to the public, although some limit availability to final findings. ${ }^{51} \mathrm{~A}$ handful of state statutes also address the availability of educational accreditation information. 52

\section{LITIGATION INVOLVING ACCESS TO ACCREDITATION INFORMATION}

Accreditation information in government hands is sought for various purposes. The loss of accreditation by a local hospital or university is obviously news of great public interest. The media have therefore sought, and occasionally obtained, accreditation information. ${ }^{53}$ Institutionalized patients have also

48. 5 U.S.C. $\$ 552(\mathrm{~b})(4)$ (1988); see HEILBRON, supra note 3, at 20 (discussing these exceptions).

49. 59 Fed. Reg. 22,250, 22,255 (1994) (to be codified at 34 C.F.R. $\$ 602.10(\mathrm{c}$ )).

50. JCAHO State Status Report, supra note 40; R.I. GEN. LAWS $§ 23-17-15.1$ (1988) (survey reports not public except insofar as director of licensing agency makes public information disclosing imminent danger to public health; accreditation reports on state institutions are also public information); see also UTAH CODE ANN. \& 26-21-9 (Supp. 1993) (public disclosure prohibited except for a summary prepared by the Department relating to licensure standards).

51. JCAHO State Status Report, supra note 40; see, e.g., GA. CODE ANN. \$ 31-7-133(b) (1991); IOWA CODE ANN. $\$ \S 135 B .12$ (for hospital accreditation, final findings only, except in licensure proceedings), 135H.13(1) (West Supp. 1993) (similarly for psychiatric hospital accreditation); WYO. STAT. \& 35-2-907(b) (Supp. 1993) (after deletion of information that identifies patients).

52. See, e.g., CONN. GEN. STAT. \& 10-239j (West Supp. 1993) ("Within forty-five days of receipt of a New England Association of Schools and Colleges accreditation report for any public school, the local or regional board of education which has jurisdiction over such school shall publicly disclose the results of the report at a public meeting of the board of education and shall make the report available for inspection upon request.").

53. Georgia Hosp. Ass'n v. Ledbetter, 396 S.E.2d 488, 490 (Ga. 1990) (Joint Commission records relied on by Department of Human Resources in licensing hospitals must be disclosed to newspapers under Georgia Open Records Act); Nassau-Suffolk Hosp. Council Inc. v. Whalen, 390 N.Y.S.2d 995, 996, 1002 (Sup. Ct. 1977) (Hospital Council brought action to enjoin disclosure of JCAH accreditation documents to newspaper; court held that under the New York Freedom of Information Act, survey reports must be disclosed if received by the Health Department without a promise of confidentiality, and withheld if received with a promise of confidentiality). 
sought information regarding the loss of accreditation by facilities in which they are institutionalized..$^{54}$

Accreditation information is also sought directly from accrediting bodies where individuals or institutions require it for their own private purposes. Most of the court cases regarding access to accreditation information involve plaintiffs in medical negligence cases who are claiming corporate negligence on the part of a hospital and are trying to gain access to accreditation documents to prove that a hospital knew or should have known of the problem that allegedly caused the injury. ${ }^{55}$ These cases generally deny discovery, but usually do so under state medical peer review statutes, requiring awkward characterizations of the Joint Commission as a "professional standards review organization"56 or an "allied medical society." 57 Providers subject to adverse accreditation actions might also seek the information on which the accreditation decision was based. ${ }^{58}$ These cases may raise issues of confidentiality of information regarding patients not involved in the litigation or by complaining patients or employees, whose privacy also deserves some respect.

\section{VI}

\section{DISCLOSURE OF ACCREDITATION INFORMATION TO CONSUMERS}

If we move into a reformed health care system based on competition among providers and networks of providers, the most important disclosure issue may become that of potential disclosure of accrediting information to consumers (or to their agents, be they health plans or health alliances) to facilitate purchasing

54. Patients of Philadelphia State Hosp. v. Commonwealth, 417 A.2d 805, 808 (Pa. Commw. Ct. 1980) (patients entitled to access to Joint Commission accreditation report on state hospital under Pennsylvania Right-to-Know Act where report relied on by state agency in licensing facility).

55. See Fretz v. Keltner, 109 F.R.D. 303, 311 (D. Kan. 1985) (plaintiffs in malpractice action sought Joint Commission accreditation documents; discovery denied as Joint Commission is a "peer review committee" within Kansas peer review protection statute, and thus documents nondiscoverable); Sherman v. District Court, 637 P.2d 378, 380, 384 (Colo. 1981) (discovery sought of Joint Commission survey report in personal injury action against hospital; court held that absent a statutory privilege, the report was not privileged; remanded to determine whether report or any part of it covered by Colorado utilization review or physician-patient privileges); Niven v. Siqueira, 487 N.E.2d 937, 942 (Ill. 1985) (plaintiffs in malpractice action sought survey reports and information submitted by hospital to Joint Commission; court held that information held by Joint Commission protected by peer review privilege statute covering "allied medical societies"); Zion v. New York Hosp., 590 N.Y.S.2d 188, 189 (App. Div.), appeal withdrawn, 81 N.Y.2d 881 (1992) (Joint Commission report denied to malpractice plaintiff because report exempt from disclosure under $\$ 6527(3)$ of the New York Education Law which exempts the records of "professional standards review organizations"); O'Neill v. McKeesport Hosp., 48 Pa. D. \& C. 3rd 115, 118 (1987) (Joint Commission documents, reports, and recommendations protected by Pennsylvania Peer Review Protection Act in medical malpractice).

56. Zion, 590 N.Y.S.2d at 189.

57. Niven, 487 N.E.2d at 942.

58. Cf. Wilfrid Academy v. Southern Ass'n of Colleges and Sch., 738 F. Supp. 200, 207 (S.D. Tex. 1990), rev'd on other grounds and vacated, 957 F.2d 210 (5th Cir. 1992) (district court determined that association acted arbitrarily and capriciously in withdrawing accreditation, in that it, inter alia, made vague and general charges and failed to provide adequate supporting information when requested to do so; Fifth Circuit reversed, holding that the district court failed to give "due deference" to association's decision). 
decisions. Similar issues may also emerge in the education area. The role of accreditation agencies as market facilitators, noted at the outset of this article, may become paramount.

If accreditation is in fact a valid measure of quality, the fact of accreditation should be useful for consumers seeking quality services. ${ }^{59}$ The fact of an adverse accreditation action might be even more relevant to decisions of whether or not to purchase services from an educational or health care institution. At a minimum, therefore, the fact of accreditation vel non must be readily available to the public if accreditation is to play any role at all in assisting consumers.

A recent survey by the Chronicle of Higher Education found that all but one of the six regional college accrediting bodies make available to the public information on college accreditation status, and several of these accrediting entities release, with the consent of the affected colleges, status reports concerning the colleges' accreditation histories. ${ }^{60}$ In early 1994 , the National Policy Board on Higher Education, representing the six regional agencies, committed itself to a policy of making available to the public reports concerning their evaluation of individual colleges and universities. ${ }^{61}$

The Joint Commission currently makes available even more information regarding health care institutions that it accredits. With respect to a particular institution, the Joint Commission discloses to inquirers the hospital's accreditation status; the number of Type 1 recommendations (recommendations for corrective action that could affect an accreditation decision) and the nature of these recommendations affecting a hospital; the hospital's accreditation history; the dates of a hospital's next survey; the status of a hospital in the accreditation process; the standards under which a survey was conducted; the hospital components involved in a survey; the standards areas involved in a complaint review; the number and nature of substantiated and substantive written complaints filed against an accredited hospital since its last regular survey; the organizational components that contributed to a decision of conditional accreditation or denial of accreditation; and whether or not there were outstanding Type 1 recommendations at the time a hospital withdrew from accreditation and the nature of those recommendations. ${ }^{62}$ Home health agency accreditation reports on which deemed status are based, as noted above, are subject to full disclosure.

More useful, however, would be information that allowed consumers to consider the opinion of the accrediting agency as to the relative quality of various accredited institutions. The Joint Commission adopted a policy on May

59. See U.S. OfFICE OF TEChNOLOGY Assessment, supra note 12, at 197-200 (discussing the validity and reliability of hospital accreditation as information for consumers).

60. Leatherman, supra note 2, at A16.

61. Samuel Weiss, College Officials Agree to Change, N.Y. TIMES, Jan. 30, 1994, at A19.

62. JOINT COMM'N ON ACCREDITATION OF HEALTHCARE ORGS., 1994 ACCREDITATION MANUAL FOR HOSPITALS xxxvii-xxxviii (1993). 
17,1993 , that proposes making available by 1994 both the substance of Type 1 recommendations and accreditation decisionmaking grids, which score performance areas such as nursing care and infection control. ${ }^{63}$ The institution would also receive an overall 1 to 100 score, thus permitting the Joint Commission to provide comparable data from similar institutions to those who request it. ${ }^{64}$ It will also provide requesters with comparative data, permitting the requester to compare the performance of an institution in a particular area to that of comparable institutions. Though questions will undoubtedly be raised as to the validity and reliability of this information, it has the potential of being very useful to consumers.

It is not coincidental that the Joint Commission has moved toward greater disclosure at this moment. The Joint Commission, like other players in the health care industry, is seeking to position itself for health care reform. Traditionally, its clients have been the hospitals it accredits, the doctors who founded it and have over the years held a majority of the positions on its governing board, and the federal and state governments that depend on the information it produces. ${ }^{65}$ In the future, consumers and their purchasing agents, who may come to depend upon the Joint Commission for comparative quality information, may be its most important clients. Other accreditors should also take note of these developments and follow suit.

\section{VII \\ CONCLUSION}

The overall trend is clearly toward greater disclosure of accreditation information. This trend is salutary, both because it makes regulation through accreditation more accountable and because it can facilitate consumer sovereignty. Though this trend may chill peer review, this effect may be minimal for two reasons. First, the movement toward greater openness of government and consumer information generally in recent years has probably lowered expectations, and thus demands, for confidentiality on the part of large educational or health care institutions with respect to accreditation information. Second, the increasing dependence of health care and educational institutions upon accreditation for securing public benefits and contracts leaves them with little choice but to pursue accreditation on whatever terms it is offered. ${ }^{66}$ These terms increasingly include public disclosure of accreditation information.

While the trend toward greater disclosure is to be applauded, ultimately it must be tempered by those concerns noted at the outset. Privacy of information regarding specific patients or students, for example, must not be compromised.

63. News Release, Joint Commission Prepares for Release of Organization-Specific Performance Data: Expands Policy on Falsification of Information (May 17, 1993) (copy on file with author).

64. Id.; see also Linda Oberman, Top Accreditor Goes Public on New Hospital Report Cards, AM. MED. NEWS, Oct. 10, 1994, at 3.

65. Jost, supra note 9.

66. Id. 
Individuals must be permitted to approach accrediting bodies with complaints or concerns regarding accredited entities without fearing disclosure of their identities. Proprietary commercial information should still be subject to general protection. In short, as accrediting bodies become more transparent, they must ultimately consider where paramount policy concerns dictate retaining certain areas of opacity, just as federal and state freedom of information acts have retained certain exceptions and have been balanced by privacy acts to strive for the correct equilibrium of disclosure and privacy where the government is involved. ${ }^{67}$

67. See 5 U.S.C. $\$ 552(a)$, (b) (1988). 
